\title{
Characteristics of Clothing Purchase Behavior in Korean Consumers of Living in America - Focusing on the Aspect of Size -
}

\author{
Jinhee Choi ${ }^{\dagger}$ \\ Dept. of Fashion Business, Jeonju University; Jeonju, Korea
}

\begin{abstract}
The purpose of this research is to suggest data available for being conducive to establishing a marketing strategy such as size of domestic clothing in global brand and producing a product of increasing consumers' satisfaction with the fit based on this research. A total of 177 questionnaires obtained from South Koreans in their 20s 50s who dwell in the state of North Carolina in America. The results follow; first, what there is significant difference in clothing purchase behavior of Koreans living according to income, duration of residence. Second, the reason for preferring Korean clothing according to educational level was the highest in the ratio of the response as saying of being 'size' with a decrease in the item of 'design'. This was because the higher in age and educational level leads to the more rise in importance of size according to a change in body type. Third, the outcome of evaluation on the fit by body part in American clothing was the largest in the response as saying of being 'similar' in the items of chest, waist, neck, arm, wrist circumference and crotch length.
\end{abstract}

Key words : clothing purchase behavior, fit, size, consumer

\section{Introduction}

Owing to the recent economic recession in the West, sales of luxury products rather goes slow, but is rapidly growing in the face of depression in the rising nations like China, India, Middle East, and Latin America. According to Kapferer \& Bastien(as cited in Kim et al., 2011), the consumption value of luxury product can be divided largely into the purchase for others and the purchase for oneself. In the rising nations, the buying motivation for others is strong that shows off social standing and financial ability. On the other hand, in Europe or America, the buying motivation for oneself functions strongly that pursues uniqueness or originative experience. Even South Korea is not exceptional. Thus, the weight of selling luxury products continues to greatly grow focusing primarily on department store(Kim et al., 2011).

The sales of prestigious brand continue. On the other hand, the environment of domestic fashion market is being shown remarkably the trend of consumers who try to buy commodity in excellent quality relatively cheaply in addition to the advancement of global brands over domestic market based on the huge capital strength and the global power(Suh \& Lee, 2011)

Examining foreign SPA(Specialty Store Retailer of Private

$\dagger$ Corresponding author; Jinhee Choi

Tel. +82-63-220-2898, Fax. +82-63-220-2736

E-mail: jhchoi@jj.ac.kr
Label Apparel) brands that are being developed at home, the SPA brands are represented by ZARA in Spain, GAP in America, and UNIQLO in Japan. According to Lee(2004)'s research, a pattern can be taken that has price competitiveness through rationalizing, planning, production, and distribution and reducing cost and that supplies timely in the right place by finding out product desired by consumer. In preparation for what the world's prestigious brand and SPA brand make an inroad into Korean fashion market in this way, it is the real situation of accelerating development in brand focusing on reasonable price, agility of absorbing trend quickly, and maintenance of new product at a store with Korean-style brand even at home(Kim \& Lee, 2007).

According to the bigger demand for clothing of finely suiting an individual's body type along with fashion trend, an interest in the clothing fit is greatly increasing as for all of the producers and consumers. Due to the prestigious brand and foreign-affiliated SPA brand, the domestic fashion market is being encroached. However, a comment on body type and size, which have great influence upon consumers' clothing satisfaction was actually difficult to be found even in domestic clothing businesses or academic researches. Accordingly, a method available for more easily grasping problems of body type and size on prestigious brand and foreign SPA brand in this way was thought to be likely possible given examining the clothing purchase behavior of Koreans living in America, who can buy this product more easily than domestic consumers.

Examining prior researches so far related to characteristics of 
clothing purchase behavior in Koreans living in America, they are as follows. There is a research(Kim, 1999) on characteristics of clothing purchase behavior under the refund policy in America unlike South Korea. There is a research(Han, 2009; Park, 2011) that compared behavior given the clothing purchase targeting university students between South Koreans and Americans. There was even a research(Kim, 2009) that analyzed difference in purchase behavior between South Korean and American consumers with the focus on the online clothing purchases. There was a research(Suh $\&$ Lee, 2011) on shopping propensity and clothing satisfaction of women in their 20s with SPA brands in America and at home according to the recent advance of domestically global SPA brand. However, in a research related to characteristics of clothing purchase behavior targeting South Koreans living in America, it was the real situation of having few researches related to the size aspect and the fit of clothing in South Koreans.

Hence, this study analyzes which difference there is in behavioral characteristics on the clothing purchase in America according to demographic factors targeting South Korean consumers from the 20 s to the $50 \mathrm{~s}$ in the state of North Carolina who are living in America for a more than 3 months or longer and have experiences in purchasing clothes. Moreover, the aim is to grasp which difference there is in selecting size between Korean and American clothes and the fit on size of American clothing by body part. The purpose is to suggest data available for being conducive to establishing a marketing strategy such as size of domestic clothing in global brand and to producing a product of increasing consumers' satisfaction with the clothing fit based on this research.

\section{Research methods}

\subsection{Research questions}

Based on the discussion above, the following propositions regarding research question 2 were developed.

First, it analyzes characteristics of clothing purchase behavior according to demographic variables of Koreans who dwell in America.

Second, it verifies the difference in size given buying Korean and American clothes and the fit of clothing by body part on American clothes.

\subsection{Measurement tool}

This research used questionnaire as tool to measure the above theories. The survey contents were as follows.

The survey contents of targeting consumers were set for a research by Kim et al.(2008) and were composed largely of 3 items. First, the matters related to respondents' demographic char- acteristics were composed of 6 items in age, gender, residence period in America, average annual income, educational level, and job. Second, the items related to the clothing purchase were composed of 9 questions such as average monthly clothing purchase cost, purchasing frequency, purchasing place, a reason for preferring American clothing, a reason for preferring Korean clothing, and preferable brand suitable for Korean body type. Third, it was composed of items such as selecting size by item in Korean clothing and American clothing and as the fit of size by part. Each item on the fit was seen in prior research(Choi \& Han, 2005) and used 5point Likert scale in 'very short or small (1 point),' 'a little short or small (2 points),' 'similar (3 points),' 'a little long or large (4 points),' and 'very long or large (5 points).'

\subsection{Data collection}

A preliminary survey was carried out targeting 10 consumers who have experienced buying and wearing American brand clothes while living in the state of North Carolina in September of 2012. Questionnaire was completed by modifying and supplementing items and problematic contents as result of survey. As the subjects of this study were South Koreans in their $20 \mathrm{~s} \sim 50 \mathrm{~s}$ who dwell in the state of North Carolina in America for more than 3 months, they were randomly extracted targeting immigrants, regular and exchange students, work trainees, exchange professors and research fellows, American company workers and their family members who have experienced purchasing and wearing American brand clothes.

The following are the survey subjects' demographic characteristics. The age distribution included, '30 39 years old' with 71 people $(40.1 \%)$. The over 40 s was shown to possess about a half with $53.1 \%$ of the whole. This was analyzed to be because of having the year of overseas research in the 40 s given having elementary school child as $23.7 \%$ of job in survey subjects corresponds to an exchange professor. Gender was indicated to be 'male' with 82 people(46.3\%) and 'female' with 95 people(53.7\%). The period of having lived in America was indicated to be 'over 3 months $\sim$ under 1 year' with 77 people(43.5\%), 'over 1 year under 3 years' with 64 people(36.2\%). Residents for a long time in more than 3 years were surveyed to be 'regular and exchange students' mostly in the academic degree course.

Job was indicated to be in order of 'educator' with 42 people(23.7\%), 'student' with 34 people(19.2\%), 'house wife' with 34 people(19.2\%). Because most of the residents such as exchange professor and public official are the married, the ratio of 'housewife' was high. The educational level was indicated to be 'master or doctorate degree' with 94 people(53.1\%). Thus, more than finishing graduate school accounts for $53.4 \%$. Most of them are exchange professors and students sent abroad. Accordingly, the 
ratio of high academic background was very high.

Period of data collection was carried out in October 2012 January 2013. Incomplete questionnaires were discarded totaling 177 usable survey questionnaires from the 200 which were distributed and answered.

\subsection{Data analysis}

Data analysis used the statistical package SPSSWIN Ver. 20.0 to analyze demographic distribution, the frequency analysis as well. To verify reliability on the fit item by part in clothing, Cronbach's Alpha value was calculated. To verify difference in characteristics of clothing purchase behavior according to demographic variables, chi-square $\left(\chi^{2}\right)$ analysis and One-way ANOVA were employed.

\section{Results and Discussion}

3.1. Characteristics of clothing purchase behavior according to demographic factors

The results that tried to examine survey subjects' clothing purchase behavior were suggested in Table 1 . The average monthly clothing purchase cost was the largest in the response as saying of expending '100 149 dollars' with 67 people(37.9\%). It was in order of '51 99 dollars' with 38 people(21.5\%). The purchasing fre- quency was 'monthly 1 2 times' with 98 people(55.9\%), thereby having been more than a half. 'Monthly 3 4 times' reached 64 people(36.2\%). The response as saying of using 'outlet' as a buying place was the largest with 89 people(50.3\%). The next was surveyed to be much used 'department store' with 36 people(20.3\%).

As a result of examining whether there is significant difference in average monthly clothing purchase cost according to age, income, and period of residence, which are demographic variables, there was statistically significant difference in all of the average monthly clothing purchase cost depending on age, income, and period of residence as suggested in Table 2. 'The 20s' was indicated to spend 'under 100 dollars' monthly on the average. 'The 30 s' was the largest in '100 150 dollars'. 'The 40 s' was similar to 'the 30s,' but was quite high even in the ratio of spending large amount in more than '200 299 dollars' relatively compared to other age groups. In other words, it was analyzed that the higher in age and income leads to the increase on average monthly clothing purchase cost. When the residence period is ' 3 months $\sim$ under 1 year', more than ' 100 dollars' was mostly spent. However, even the ratio of spending large cost in 'more than 200 dollars' was the highest. Unlike age and income, the shorter residence period led to the largest clothing purchase cost. This cause was analyzed that the shorter residence period leads to the larger demand for the clothing

Table 1. Subjects' clothing purchase behavior

\begin{tabular}{ccccccc}
\hline Variable & \multicolumn{3}{c}{ Frequency(\%) } & Total \\
\hline \multirow{2}{*}{ Purchase times } & $1 \sim 2$ times & $3 \sim 4$ times & $5 \sim 6$ times & 7 times over & - & $177(100.0)$ \\
& $98(55.9)$ & $64(36.2)$ & $13(7.3)$ & $1(0.6)$ & - & Multi \\
\hline \multirow{2}{*}{ Place } & Online shopping & Department store & Outlet mall & Retail shop & $177(100.0)$ \\
& $8(4.5)$ & $36(20.3)$ & $89(50.3)$ & $32(18.1)$ & $12(6.8)$ & \\
\hline
\end{tabular}

Table 2. Monthly clothing purchase cost depending on age, income, and period of residence

\begin{tabular}{|c|c|c|c|c|c|c|c|c|}
\hline & Variable & $\begin{array}{c}50 \\
\text { dollars }\end{array}$ & $\begin{array}{l}\text { 51 99 } \\
\text { dollars }\end{array}$ & $\begin{array}{c}100 \sim 149 \\
\text { dollars }\end{array}$ & $\begin{array}{c}150 \sim 199 \\
\text { dollars }\end{array}$ & $\begin{array}{c}200 \sim 299 \\
\text { dollars }\end{array}$ & Total & $\chi^{2}$ \\
\hline \multirow{4}{*}{ Age } & 20 29years & $6(4.4)$ & $4(2.3)$ & $0(0.0)$ & $0(0.0)$ & $2(1.1)$ & $12(6.8)$ & \multirow{4}{*}{$49.138 * * *$} \\
\hline & 30 39years & $6(4.4)$ & $23(13.0)$ & $30(17.0)$ & $0(0.0)$ & $12(6.8)$ & $71(30.1)$ & \\
\hline & $40 \sim 59$ years & $8(4.5)$ & $11(6.2)$ & $37(20.9)$ & $18(10.2)$ & $20(11.3)$ & $94(64.1)$ & \\
\hline & Total & $20(11.3)$ & $38(21.5)$ & $67(37.9)$ & $18(10.2)$ & $34(19.2)$ & $177(100.0)$ & \\
\hline \multirow{5}{*}{ In-come } & under $\$ 10,000$ & $2(1.1)$ & $0(0.0)$ & $0(0.0)$ & $0(0.0)$ & $2(1.1)$ & $4(2.3)$ & \multirow{5}{*}{$94.055^{* * *}$} \\
\hline & $\$ 10,000 \sim 29,999$ & $10(5.6)$ & $8(4.6)$ & $2(1.1)$ & $0(0.0)$ & $0(0.0)$ & $20(11.3)$ & \\
\hline & $\$ 30,000 \sim 49,999$ & $4(2.3)$ & $1(0.6)$ & $8(4.5)$ & $6(3.4)$ & $8(4.5)$ & $27(15.2)$ & \\
\hline & over $\$ 50,000$ & $4(2.3)$ & $29(16.4)$ & $57(32.3)$ & $12(6.8)$ & $24(13.6)$ & $126(71.2)$ & \\
\hline & Total & $20(11.3)$ & $38(21.5)$ & $67(37.9)$ & $18(10.2)$ & $34(19.2)$ & $177(100.0)$ & \\
\hline \multirow{4}{*}{$\begin{array}{l}\text { Period of } \\
\text { residence }\end{array}$} & 3months under 1year & $4(2.3)$ & $12(6.8)$ & $33(18.7)$ & $6(3.4)$ & $22(3.4)$ & $77(43.5)$ & \multirow{4}{*}{$38.789 * * *$} \\
\hline & 1 3years & $4(2.3)$ & $14(0.0)$ & $30(17.0)$ & $8(4.5)$ & $8(4.5)$ & $64(36.1)$ & \\
\hline & $3 \sim 5$ years & $12(6.8)$ & $12(6.8)$ & $4(2.2)$ & $4(2.3)$ & $4(2.3)$ & $36(20.3)$ & \\
\hline & Total & $20(11.3)$ & $38(21.5)$ & $67(37.9)$ & $18(10.2)$ & $34(19.2)$ & $177(100.0)$ & \\
\hline
\end{tabular}

$* * * p<.001$ 
Table 3. Clothing purchase and the place depending on age

\begin{tabular}{|c|c|c|c|c|c|c|c|c|}
\hline & \multirow{2}{*}{ Variable } & \multicolumn{6}{|c|}{ Frequency(\%) } & \multirow{2}{*}{$\chi^{2}$} \\
\hline & & One-line Shop & Department store & Outlet & Multi- Selected shop & Retail shop & Total & \\
\hline \multirow{4}{*}{ Age } & 20 29years & $0(0.0)$ & $4(2.3)$ & $2(1.1)$ & $4(2.3)$ & $2(1.1)$ & $12(6.8)$ & \multirow{4}{*}{$31.364^{* *}$} \\
\hline & 30 39years & $8(4.5)$ & $16(9.0)$ & $37(20.9)$ & $6(3.4)$ & $4(2.3)$ & 71(40.1) & \\
\hline & 40 59years & $0(0.0)$ & $16(9.0)$ & $50(28.3)$ & $22(12.4)$ & $6(3.4)$ & $94(53.1)$ & \\
\hline & Total & $8(4.5)$ & $36(20.3)$ & $89(50.3)$ & $32(18.1)$ & $12(6.8)$ & $177(100.0)$ & \\
\hline
\end{tabular}

$* * p<.01$

low income as regular or exchange students, and that residents for a long time are few in the average monthly clothing purchase cost because of having relatively a lot of opportunities to purchase clothes compared to residents for a short period of time.

As a result of examining whether there is significant difference in the average monthly clothing purchase and the place where it was purchased according to age and income, which are demographic variables, there was significant difference in clothing purchase the place where it was purchased depending on age and income as suggested in Table 3. 'The 20s' has small income and possesses the majority in 'monthly 1 2 times' with 10 people among 12 subjects even in the clothing purchase frequency itself. Thus, there was no difference in the buying place. 'The 30s' was the largest in 'outlet' with 37 people and was indicated to be in order of 'department store.' On the other hand, even 'the 40s' was the largest in 'outlet', but was considerably high in the ratio of 'multi-selected shop(T. J. MAX, Marchael, etc.),' which is distribution type that doesn't exist in South Korea. This reason was analyzed that multi-selected shop is preferred because of being short in shopping distance and of possessing diverse products up to housewares including fashion as a shop of being not larger compared to outlet, thereby being available for shopping everything at a time. Accordingly, it is thought to be needed a consideration on distribution pattern like America's 'multi-selected shop' similar to what combined mart and outlet in South Korea for the age group in 'more than the 40s' even in South Korea.

As a result of examining whether significant difference appears in a reason for preferring Korean clothing in comparison with American clothing according to age, educational level, and residence period, there was significant difference in a reason for preferring Korean clothing depending on age, income, and residence period as suggested(Table 4). In 'under the 30s,' a reason for preferring Korean clothing compared to American clothing was the largest in 'design'. The next as shown preference in the 'fabric'. In 'more than the 40s,' the preference for 'design' decreased. The preference for 'size' got higher compared to the age group in 'under the 30s.' This cause was analyzed that the preference for 'size' in American clothing couldn't help dropping because the more age leads to being noticeable in change of body type. In educational level, the higher academic background led to the reduction in response as saying of 'design' and to the increase in response as saying of 'size' among reasons for preferring Korean clothing.

Table 4. Difference in a reason for preferring Korean clothing depending on age, income, and residence period

\begin{tabular}{|c|c|c|c|c|c|c|c|c|}
\hline & \multirow{2}{*}{ Variable } & \multicolumn{6}{|c|}{ Frequency $(\%)$} & \multirow{2}{*}{$\chi^{2}$} \\
\hline & & Design & Size & Return service & Fabric & Etc. & Total & \\
\hline \multirow{4}{*}{ Age } & 20 29years & $8(4.5)$ & $4(2.3)$ & $0(0.0)$ & $0(0.0)$ & $0(0.0)$ & $12(6.8)$ & \multirow{4}{*}{$48.023 * * *$} \\
\hline & 30 39years & $46(26.0)$ & $4(2.3)$ & $0(0.0)$ & $19(10.7)$ & $2(1.1)$ & $71(40.1)$ & \\
\hline & 40 59years & $30(16.9)$ & $28(15.8)$ & $4(2.3)$ & $20(11.3)$ & $12(5.6)$ & 9453.1) & \\
\hline & Total & $84(47.5)$ & $36(20.3)$ & $4(2.3)$ & $39(22.0)$ & $14(6.7)$ & $177(100.0)$ & \\
\hline \multirow{5}{*}{$\begin{array}{c}\text { Educational } \\
\text { level }\end{array}$} & High school & $2(1.1)$ & $0(0.0)$ & $0(0.0)$ & $0(0.0)$ & $0(0.0)$ & $2(1.1)$ & \multirow{5}{*}{$58.936 * * *$} \\
\hline & Bachelor & $38(21.5)$ & $8(4.5)$ & $4(2.3)$ & $31(17.5)$ & $0(0.0)$ & $81(45.8)$ & \\
\hline & Master & $26(14.7)$ & $10(5.6)$ & $0(0.0)$ & $2(1.1)$ & $8(4.5)$ & $46(26.0)$ & \\
\hline & Doctor & $18(10.2)$ & $18(10.2)$ & $0(0.0)$ & $6(3.4)$ & $6(3.4)$ & $48(27.1)$ & \\
\hline & Total & $84(47.5)$ & $36(20.3)$ & $4(2.3)$ & $39(22.0)$ & $14(6.7)$ & $177(100.0)$ & \\
\hline \multirow{4}{*}{$\begin{array}{l}\text { Period of } \\
\text { residence }\end{array}$} & 3months 1year & $36(20.3)$ & $22(12.4)$ & $2(1.1)$ & $15(8.5)$ & $2(1.1)$ & $77(43.5)$ & \multirow{4}{*}{$37.717 * * *$} \\
\hline & 1 3years & $26(14.7)$ & $8(4.5)$ & $2(1.1)$ & $18(10.2)$ & $10(5.6)$ & $64(36.2)$ & \\
\hline & 3 5years & $22(12.4)$ & $6(3.4)$ & $0(0.0)$ & $6(3.4)$ & $2(1.1)$ & $36(20.3)$ & \\
\hline & Total & $84(47.5)$ & $36(20.3)$ & $4(2.3)$ & $39(22.0)$ & $14(6.7)$ & $177(100.0)$ & \\
\hline
\end{tabular}

$* * * p<.001$ 
Table 5. Reason for preferring American clothing

\begin{tabular}{|c|c|c|c|c|c|c|c|}
\hline & \multirow{2}{*}{ Variable } & \multicolumn{5}{|c|}{ Frequency $(\%)$} & \multirow{2}{*}{$\chi^{2}$} \\
\hline & & Design & Price & Size & Return Service & Total & \\
\hline \multirow{4}{*}{$\begin{array}{c}\text { Residence } \\
\text { period }\end{array}$} & 3months $\sim$ under 1year & $0(0.0)$ & $65(36.7)$ & $0(0.0)$ & $12(6.8)$ & $77(43.5)$ & \multirow{4}{*}{$19.026 * *$} \\
\hline & $1 \sim$ under 3years & $2(1.1)$ & $40(22.6)$ & $0(0.0)$ & $22(12.4)$ & $64(36.2)$ & \\
\hline & 3 under 5years & $0(0.0)$ & $24(13.6)$ & $2(1.1)$ & $10(5.6)$ & $36(20.3)$ & \\
\hline & Total & $2(1.1)$ & $129(72.9)$ & $2(1.1)$ & $44(24.9)$ & $177(100.0)$ & \\
\hline \multirow{8}{*}{ Job } & Students & $0(0.0)$ & $24(13.6)$ & $0(0.0)$ & $10(5.6)$ & $34(19.2)$ & \multirow{8}{*}{$102.293 * * *$} \\
\hline & Office Worker & $0(0.0)$ & 19(10.7) & $0(0.0)$ & $6(3.4)$ & $25(14.1)$ & \\
\hline & Professor \& Researcher & $0(0.0)$ & $36(20.3)$ & $2(0.0)$ & $8(4.6)$ & $46(47.1)$ & \\
\hline & Public Official & $0(0.0)$ & $20(11.2)$ & $0(0.0)$ & $6(3.4)$ & $26(14.7)$ & \\
\hline & Judical Official \& Medical Personnel & $0(0.0)$ & $6(3.4)$ & $0(0.0)$ & $2(1.1)$ & $8(4.6)$ & \\
\hline & House wife & $2(1.1)$ & $20(11.2)$ & $0(0.0)$ & $12(6.8)$ & $34(19.2)$ & \\
\hline & Etc. & $0(0.0)$ & $4(2.3)$ & $0(0.0)$ & $0(0.0)$ & $4(2.3)$ & \\
\hline & Total & $2(1.1)$ & $129(72.9)$ & $2(1.1)$ & $44(24.9)$ & $177(100.0)$ & \\
\hline
\end{tabular}

$* * p<.01, * * * p<.001$

Even this cause was analyzed to be related even to a change in body type according to age. People with academic background in more than 'university graduate' were surveyed to prefer Korean clothing more especially in 'fabric'. Like age and educational level, the residence period was reduced preference for 'design' in the longer residence period, but was decreased preference even for 'size' equally. This cause is considered to be because the probability gets higher that acquires a method of choosing size suitable for own body type and of finding brand suitable for own body type in the more passage of time even if there were many dissatisfactions with 'size' during the early settlement.

As a result of examining whether there is significant difference in a reason for preferring American clothing in comparison with Korean clothing according to residence period and job, there was significant difference as suggested in Table 5. The biggest reason for preferring American clothing compared to Korean clothing was absolutely high in both of residence period and job. The next was surveyed to be in order of 'return and exchange service'. Especially, as the preference for 'price' got lower in the longer residence period, the weight onreturn and exchange service' got higher. This was same as the outcome by $\operatorname{Kim}(1999)$ as saying that the refund policy leads to making purchase decision easy especially in case of family members' clothes and to getting smaller in perceiving risk given buying clothes when making a decision of buying clothes. Even according to job, the significant difference was shown in a reason for preferring American clothing. 'Price' was the biggest reason. The next was 'return and exchange service'. Relatively compared to educators, research fellows, and public officials, the students and housewives were high in weight one 'return and exchange service'. This was analyzed that the importance of this return service is relatively high mostly in case of students with small income and of housewives in charge primarily of buying clothes.

A reason for purchasing American clothing as a gift was possessed the majority with 153 people( $86.4 \%$ ) by the response as saying of 'being able to buy product in the same brand, which is sold at home, but cheaper'. The response as saying of being because of 'being easy for buying luxury brand product' reached 22 people(12.4\%). The response as saying of being 'because of being excellent in design and color' reached just 2 people(1.1\%). This outcome is considered that there will be a need of adjusting domestic sale price of overseas brand because the domestic sale price of American clothing product is being sold at absurdly high price compared to the local price even if taking into account the logistics cost and the royalty cost of being paid to brand.

There was no significant difference in the monthly clothing purchase, the place and a reason for preferring American and Korean clothing according to gender.

\subsection{Choice of size given purchasing American clothes}

The results of having surveyed how consumers select size given buying American clothing different from size of Korean clothing by gender and by item were indicated in Table 6 and Table 7 . Korean consumers select clothing without knowing specific size of American clothing. Thus, it compared sequentially from the smallest size to the largest size between Korean and American clothes regardless of actual size. It allowed Korean size in 44, 55, 66, 77, 88 to correspond respectively to American size in $0,2,4,6,8$. The sizes $80,85,90,95,100$ were allowed to be selected with XS, S, M, L, XL. For example, woman consumers select the size 66 in 
Table 6. Women's criterion of selecting size of American clothing

\begin{tabular}{|c|c|c|c|c|c|c|}
\hline 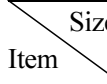 & $\begin{array}{l}\text { wo-step } \\
\text { bigger }\end{array}$ & $\begin{array}{c}\text { One-step } \\
\text { bigger }\end{array}$ & $\begin{array}{l}\text { Same } \\
\text { size }\end{array}$ & $\begin{array}{l}\text { One-step } \\
\text { smaller }\end{array}$ & $\begin{array}{l}\text { Two-step } \\
\text { smaller }\end{array}$ & Total \\
\hline Jacket & $1(1.1)$ & $8(8.4)$ & $39(41.1)$ & $34(35.8)$ & $13(13.7)$ & $95(100.0)$ \\
\hline Shirts & $0(0.0)$ & $16(16.8)$ & $30(31.6)$ & $37(38.9)$ & $12(12.6)$ & $95(100.0)$ \\
\hline Pants & $10(10.5)$ & $31(32.6)$ & $37(38.9)$ & $15(15.8)$ & $2(2.1)$ & $95(100.0)$ \\
\hline Brief & $0(0.0)$ & $14(14.7)$ & $42(44.2)$ & $33(34.7)$ & $6(6.3)$ & $95(100.0)$ \\
\hline
\end{tabular}

Korean clothing but 4 or 6 size in American clothing.

Examining women's criterion of selecting size of American clothing in Table 6, they gave response as saying of selecting 'same size' as Korean clothing size in all items. The next order was given response as saying of selecting 'one-step smaller'. In other words, it was surveyed that most of them select size 4 when Korean clothing size is 66 or that some select one-step smaller size 2. Pants had high ratio in the response as saying of selecting 'one-step bigger' size compared to other items. For this reason, it can guess that the bigger size is selected by respondents who feel uncomfortable because the American clothing is relatively short in crotch length of having great influence upon the fit of pants other than waist circumference and hip circumference when considering that the ratio of response as saying that the crotch length is 'a litter shorter' had been high with 30 people(16.9\%) in Table 9. However, it is what is contrary to the outcome of Table 9, which is high in the ratio of response as saying that the leg length of American clothing is very big. The detailed cause is considered that a comparative research will need to be performed on body size by part between Koreans and Americans in a future research.

Examining men's criterion of selecting size of American clothing in Table 7, the ratio of the response as saying of selecting 'same size' as the Korean clothing size in items of 'shirts' and 'pants.' All were the highest with 50 people(61.0\%). In 'shirts' and 'pants' the ratio of selecting 'one-step smaller' was indicated to be 46 people(56.1\%) and 55 people(31.1\%), respectively. This is the outcome same as the response as saying that the American clothing size is big in most parts as can be seen in Table 9. Men were indicated to have almost no case of selecting the American clothing size bigger than Korean clothing when being compared with women. Thus, the response as saying of being 'a little smaller' in

Table 7. Men's criterion of selecting size of American clothing

\begin{tabular}{|c|c|c|c|c|c|c|}
\hline & $\begin{array}{c}\text { Two-step } \\
\text { bigger }\end{array}$ & $\begin{array}{c}\text { One-step } \\
\text { bigger }\end{array}$ & $\begin{array}{l}\text { Same } \\
\text { size }\end{array}$ & $\begin{array}{l}\text { One-step } \\
\text { smaller }\end{array}$ & $\begin{array}{l}\text { Two-step } \\
\text { smaller }\end{array}$ & Total \\
\hline Jacket & $0(0.0)$ & $0(0.0)$ & $24(29.3)$ & $46(56.1)$ & $12(14.6)$ & $82(100.0)$ \\
\hline Shirts & $0(0.0)$ & $2(2.4)$ & $50(61.0)$ & $26(31.7)$ & $4(4.9)$ & $82(100.0)$ \\
\hline Pants & $0(0.0)$ & $2(2.4)$ & $50(61.0)$ & $18(22.0)$ & $12(6.8)$ & $82(100.0)$ \\
\hline Brief & $0(0.0)$ & $0(0.0)$ & $14(17.1)$ & $55(31.1)$ & $13(7.3)$ & $82(100.0)$ \\
\hline
\end{tabular}

Table 8. Fit of American clothing by body part according to gender

\begin{tabular}{lccccc}
\hline \multicolumn{1}{c}{ Measurements item } & Sex & $\mathrm{N}$ & Mean & SD & t-value \\
\hline \multirow{2}{*}{ Bust Circumference } & Male & 82 & 3.40 & .718 & \multirow{2}{*}{ …061* } \\
& Female & 95 & 3.51 & .543 & \\
Waist Circumference & Male & 82 & 3.27 & .545 & \\
& Female & 95 & 3.38 & .639 & $-1.243^{*}$ \\
Hip Circumference & Male & 82 & 3.34 & .571 & \\
& Female & 95 & 3.43 & .647 & $-0.984^{*}$ \\
Shoulder Width & Male & 82 & 3.29 & .638 & \\
& Female & 95 & 2.98 & .729 & \\
\hline
\end{tabular}

${ }^{*} p<.05,{ }^{* *} p<.01$

crotch length and arm circumference shown in Table 9 corresponds to women.

\subsection{Evaluation of the fit by body part given buying American clothing}

Difference in the fit of American clothing by body part according to gender was proposed in Table 8. There was significant difference in the fit according to gender only in chest size, waist circumference, hip circumference, and shoulder width. Neck circumference, arm circumference, wrist circumference, sleeve length, leg length, and crotch length were analyzed to have no significant difference. In the parts of chest size, waist circumference, and hip circumference, women gave evaluation on the fit as saying of being 'a little bigger or longer' compared to men. In the item of shoulder width, women felt that it is 'similar'.

On the other hand, men evaluated that it is 'a little big'. Accordingly, it was analyzed that the imported brand needs to adjust size more in detail on this part given manufacturing clothes for domestic consumers(Table 9). As a result of reliability analysis (Cronbach's alpha) on item of the fit by part, the coefficient was indicated to be 0.729 . Thus, reliability of item was high. The fit by part on American clothing was the largest in the response as saying of being 'similar' with $53.1 \%$ in chest size, $63.8 \%$ in waist circumference, $67.2 \%$ in neck circumference, $50.8 \%$ in arm circumference, $54.2 \%$ in wrist circumference, and $55.9 \%$ in crotch length. Hip circumference accounted for $51.4 \%$ in 'a little big' thereby having been slightly higher than $45.2 \%$ in 'similar'. Unlike other parts, the sleeve length and the leg length were the largest in 'a little big', respectively, with $57.6 \%$ and $53.1 \%$. 'Very big' was also indicated to be $36.2 \%$ and $33.3 \%$. Thus, respondents were analyzed to have the lowest satisfaction with these parts. This can be expected that there is the biggest difference in items of sleeve length and leg length between American body type and Korean body type. In the crotch length, 'similar' was the largest with possessing 55.9\%. However, even the response as saying of being 'a little small' 
Table 9. Evaluation on the fit by body part in American clothing

\begin{tabular}{lcccccc}
\hline \multicolumn{1}{c}{ Measurement item } & Very small & A little small & Similar & A little big & Very big & Total \\
\hline Bust Circumference & $0(0.0)$ & $5(2.8)$ & $94(53.1)$ & $70(39.5)$ & $8(4.5)$ & $177(100.0)$ \\
Waist Circumference & $0(0.0)$ & $6(3.4)$ & $113(63.8)$ & $52(29.4)$ & $6(3.4)$ & $177(100.0)$ \\
Hip Circumference & $0(0.0)$ & $4(2.3)$ & $80(45.2)$ & $91(51.4)$ & $2(1.1)$ & $177(100.0)$ \\
Neck Circumference & $0(0.0)$ & $6(3.4)$ & $119(67.2)$ & $48(27.1)$ & $4(2.3)$ & $177(100.0)$ \\
Upper Arm Circumference & $0(0.0)$ & $10(5.6)$ & $90(50.8)$ & $71(40.1)$ & $6(3.4)$ & $177(100.0)$ \\
Wrist Circumference & $0(0.0)$ & $8(4.5)$ & $96(54.2)$ & $69(39.0)$ & $4(2.3)$ & $177(100.0)$ \\
Shoulder Width & $0(0.0)$ & $6(3.4)$ & $71(40.1)$ & $96(54.2)$ & $4(2.3)$ & $177(100.0)$ \\
Sleeve Length & $0(0.0)$ & $0(0.0)$ & $11(6.2)$ & $102(57.6)$ & $64(36.2)$ & $177(100.0)$ \\
Leg Length & $0(0.0)$ & $2(1.1)$ & $22(12.4)$ & $94(53.1)$ & $59(33.3)$ & $177(100.0)$ \\
Crotch Length & $0(0.0)$ & $30(16.9)$ & $99(55.9)$ & $44(24.9)$ & $4(2.3)$ & $177(100.0)$ \\
\hline
\end{tabular}

accounted for $16.9 \%$, thereby having been higher compared to other parts. This reason was analyzed that the ratio of selecting 'one-step bigger' rather than Korean size is higher than other parts when women select American pants in Table 6.

The outcome of evaluation on the fit by body part in American clothing was suggested in Table 9 outcome, which carried out OneWay ANOVA in order to figure out the difference in the fit by part according to residence period, was suggested in Table 10. The partbased fit according to residence period had statistically significant difference in items of chest size, waist circumference, hip circumference, and shoulder width. The shoulder width was given the response as saying of being most 'similar' in the fit in case of being ' 1 year 3 years'. However, the items of chest size, waist circumference, hip circumference, and shoulder width as a whole could be considered to be moved the fit from 'a little big' to 'similar' according to the longer residence period. This cause is considered to be because of having purchased brand suitable for own body type along with a psychological cause of getting accustomed to the size and the fit on American clothing according to the longer residence period.

\section{Conclusions}

This analyzed the characteristics of clothing purchase behavior in Koreans living in America and further analyzed differences in the fit of size by body part, thereby having aimed to be conducive to establishing a marketing strategy such as size of domestic clothing in global brands at home and abroad. Summarizing the results of this study, they are as follows.

First, there is significant difference in clothing purchase behavior of Koreans living in America according to demographic variables that follows. The higher in age and income led to the increase in average monthly clothing purchase cost. On the other hand, the shorter residence period led to the more clothing purchase cost. This was analyzed due to the shorter residence period leads to the bigger demand for the clothing purchase.

Second, as to a reason for preferring Korean clothing compared to American clothing according to age, the biggest reason was indicated to be 'design' in young age group in less than 'the 30 s' and to be 'size' in more than 'the 40s'. A reason for preferring Korean clothing according to the higher educational level was the highest in the ratio of the response as saying of being 'size' with a decrease in the item of 'design'. This was because the older in age and educational level leads to the increase in importance of size according to a change in body type. However, the reason for preferring American clothing compared to Korean clothing in the longer residence period got higher in the response as saying of 'return and exchange services' with a decrease in preference for 'price'. Also, even in job, most of the jobs had the response as saying that 'price' is the biggest preference reason for American clothing. On the other

Table 10. Fit by part according to residence period

\begin{tabular}{|c|c|c|c|c|c|c|c|}
\hline \multirow{2}{*}{ Measurements item } & \multicolumn{2}{|c|}{ 3month under 1year } & \multicolumn{2}{|c|}{ 1year $\sim$ under 3years } & \multicolumn{2}{|c|}{ 3years $\sim$ under 5years } & \multirow{2}{*}{ F-value } \\
\hline & $\mathrm{M}$ & S.D & $\mathrm{M}$ & S.D & $\mathrm{M}$ & S.D & \\
\hline Bust Circumference & 3.57 & .696 & 3.42 & .570 & 3.34 & .630 & $2.413^{* *}$ \\
\hline Waist Circumference & 3.40 & .654 & 3.31 & .560 & 3.19 & .525 & $1.526^{*}$ \\
\hline Hip Circumference & 3.49 & .576 & 3.33 & .668 & 3.28 & .566 & $2.052 *$ \\
\hline Shoulder Width & 3.36 & .738 & 2.97 & .666 & 3.14 & .639 & $3.737 * *$ \\
\hline
\end{tabular}

${ }^{*} p<.05,{ }^{* *} p<.01$ 
hand, the students with small income and the housewives who need to buy clothes for family members other than themselves gave the response as saying that the biggest preference reason is 'return and exchange services'. Seeing this, housewives' purchasing power is the highest even in Korean clothing industry. Thus, there was a need of further strengthening service competitiveness on return and exchange.

Third, Korean's criterion of selecting American clothing size were the highest in the response as saying of choosing 'same size' as Korea's clothing size in all of the male and female items. The next was chosen size that is 'one-step smaller'. However, women's pants had the high ratio of the response as saying of selecting onestep bigger size unlike other items. This led to selecting the bigger size because of feeling uncomfortable due to being relatively shorter in American clothing as for the crotch length of having great influence upon the fit of pants except waist circumference or hip circumference. A research is considered to be likely needed more on crotch length when manufacturing product in overseas brand.

Fourth, the outcome of evaluation on the fit by body part in American clothing was the largest in the response as saying of being 'similar' in the items of chest size, waist circumference, neck circumference, arm circumference, wrist circumference, and crotch length. In hip circumference, the ratio of the response as saying of being 'a little big' was slightly higher than being 'similar'. The items of sleeve length and leg length were possessed more than a half by 'a little big'. Even 'very big' was indicated to be $30 \%$. Thus, the satisfaction with the fit of this part was analyzed to be the lowest. This can be expected that there is the biggest difference in items of sleeve length and leg length between American body type and Korean body type. Accordingly, a research on size was further needed on global brand in the future.

This study cannot perfectly generalize and has limitation in the results due to geographical restrictions. Hence, the aim is to suggest the direction of follow-up research as follows. A research will need to be performed so that specific information can be offered to companies through analyzing substantial size data as for difference in size of body part according to characteristics of American and
Korean body types.

\section{References}

Choi, J. H., \& Han, J. Y. (2005). A study on the production condition and satisfaction with knitted jacket for the middle-aged women. Journal of the Korean Society of Clothing and Textiles, 29(8), 1068-1078.

Han, M. S. (2009). A cross-cultural study on the clothing purchasing behavior. The Research Journal of the Costume Culture, 17(1), 163.

Kapferer, J., \& Bastin, V. (2009). The specificity of luxury management: Turning marketing upside down. Journal of Brand Management, 16(5/6), 311-322. doi: 10.1057/bm.2008.51

Kim, E. Y. (2009). A comparison of the benefits for online clothing purchases between Koreans and U. S. consumers. Journal of the Korean Society of Clothing and Textiles, 33(7), 1074-1075.

Kim, M. Y. (1999). The characteristics of clothing buying behavior under the refund policy of U. S. stores. Journal of the Korean Society of Clothing and Textiles, 23(3), 363-368.

Kim, H. S., Choo, H. J., \& Kim, S. J. (2008). Clothing consumption expenditures and heavy buying motivations for heavy clothing buyers. Journal of the Korean Consumption Culture, 11(4), 73-93.

Kim, H. S., Moon, H. G., Choo, H. J., \& Yoon, N. H. (2011). The effect of fashion luxury consumption values on the intention to maintain brand relationships- Differences among segmented markets based on purchasing patterns. Journal of the Korean Society of Clothing and Textiles, 35(4), 408-420.

Kim, H. J., \& Lee, S. H. (2007). An analysis of consumer's buying behavior and the importance of store attributes in SPA brand Focused on female college student in Seoul metropolitan area and Gyeonggi-Do area. The Research Journal of the Costume Culture, 15(3), 369-382.

Lee, S. A. (2004). Marketing strategy of Korean SPA brands. Journal of the Human Life and Environment, (2), 1-15.

Park, E. J. (2011). Apparel impulse buying and shopping emotion: Does it differ between Korea and the US?. Korean Journal of Human Ecology, 20(2), 401-402.

Suh, H. K., \& Lee, S. H. (2011). Shopping orientation and satisfaction with clothes of 20 s women consumers using domestic/global SPA brands. Journal of the Korean Society of Clothing and Textiles, 35(5), 501-502.

(Received 19 November 2013; 1st Revised 10 December 2013; 2nd Revised 29 January 2014; Accepted 8 March 2014)

Copyright (C) 2014 (by) the authors. This article is an open access article distributed under the terms and conditions of the Creative Commons Attribution license (http://creativecommons.org/licenses/by/3.0/), which permits unrestricted use, distribution, and reproduction in any medium, provided the original work is properly cited. 